\title{
PENINGKATAN KEMAMPUAN BERBICARA BAHASA INGGRIS MELALUI MEDIA GAMBAR BERSERI
}

\author{
La Ode Muhammad Idrus Hamid B. \\ Universitas Negeri Jakarta idrusaldiano@,yahoo,co.id
}

\begin{abstract}
Abstrak
Tujuan daripenelitian ini adalah untuk meningkatkan kemampuan berbicara bahasa Inggris siswa melalui media gambar berseri. Penelitian ini merupakan penelitian campuran dengan metode penelitian tindakan di SMA Negeri 5 Kendari, Sulawesi Tenggara. Data penelitian ini diambil pada semester kedua di kelas XI IA 2 yang beranggotan 42 orang siswa dan dianalisis secara kualitadf dan kuantitatif. Secara kuantitatif, ditemukan bahwa kemampuan berbicara siswa meningkat dengan signifikan dari siklus pertama hingga siklus ketiga. Oleh sebab itu, dapat disimpulkan bahwa kemampuan berbicara siswa dapat ditingkatkan dengan menggunakan media gambar berseri. Bagi guru sangat disarankan agar menggunakan media gambar berseri sebagai salah satu teknik dalam mengajarkan kemampuan berbicara bahasa Inggris. Selain itu, juga direkomendasikan kepada peneliti lain agar menggunakan penelitian ini untuk penelitian selanjutnya.
\end{abstract}

Kata Kunci: kemampuan berbicara, gambar berseri, penelitian tindakan

\begin{abstract}
The ocjetive of this research was to improve the students' speaking ability in English language through sequence picture media. It was a mixed research with action research method in SMA Negeri 5 Kendari, Sulawesi Tenggara. The research data were taken in the second semester of XI IA 2 class with 42 students and analyzed qualitatively and quantitatively. The data were collected through observation and test. The data analysis and interpretation indicated that there is an improvement in students' spealdng ability. Quantitavely, it was found that the students' speaking ability increased significantly from the first until third cycles. Therefore, it concluded that the students' speaking ability can be improved by using sequence picture media. The finding lead to the recomendation for the teachers to use sequence picture as an alternative technique in teaching speaking English ability. It also recomended to other researcher for continue research.
\end{abstract}

Keywords: speaking ability, sequence picture, action research 


\section{PENDAHULUAN}

Bahasa merupakan alat komunikasi lisan manusia yang sangat penting dan lisan merupakan media utama, demikian halnya dengan bahasa Inggris. Bahasa Inggris dijadikan sebagai bahasa kedua baik dalam proses kegiatan formal maupun nonformal. Penggunaan bahasa asing sebagai alat komunikasi lisan sering dijumpai dalam komunikasi sehari-hari. Jack C. Richard (2002:201) menyatakan bahwa presentasi terbesar bagi siswa yang belajar bahasa didunia, mereka belajar bahasa Inggris adalah untuk mengembangkan kecakapan berbicaranya. Oleh karena itu, berbicara tidak cukup mengandalkan kemampuan penguasaan kosa kata, tetapi juga harus memiliki pengetahuan gramatika yang memadai.

Sebagai salah satu aspek berbahasa, berbicara menduduki peran penting dalam kehidupan sosial sehingga kemampuan berbicara mudak harus dikuasai oleh siapa pun. Thomrnbury (2006:1) menyatakan bahwa berbicara adalah suatu hal yang alamiah dan integral sehingga kita lupa bagaimana pertama kali memperoleh dan mampu berbicara, karena itu ketika kita ingin menguasai bahasa asiing kita harus belajar kembali.

Bahasa Inggris merupakan salah satu mata pelajaran yang diajarkan di sekolah sekolah di Indonesia sejak dari sekolah dasar sampai perguruan tinggi. Bahasa Inggris juga merupakan bahasa kedua atau bahasa asing yang diajarkan disekolah setelah bahasa pertama atau bahasa Indonesia. Oleh karenanya penguasaan bahasa baik lisan, tulisan dan isyarat merupakan hal yang ddak dapat dihindari termasuk bahasa Inggris sebagai bahasa internasional, membuka cakrawala dunia dan komunikasi masyarakat global.

Di samping itu, bahasa Inggris merupakan alat untuk berkomunikasi secara lisan dan tulis. Berkomunikasi yang kita ketahui adalah memahami dan mengungkapkan informasi, pikiran, perasaan dan mengembangkan ilmu pengetahuan, teknologi, dan budaya. Kemampuan berkomuniasi disini dalam artian kemampuan berwacana yakni mampu memahami dan menghasilkan teks lisan atau tulisan yang direalisasikan dalam dua keterampilan berbahasa, yaitu keterampilan reseptif dan keterampilan produkdf. Keterampilan reseptif meliputi keterampilan menyimak (listening) dan keterampilan membaca (reading, sedangkan keterampilan produktif meliputi keterampilan berbicara (speaking dan keterampilan menulis (speaking. Oleh karena itu, mata pelajaran bahasa Inggris diarahkan untuk mengembangkan keterampilan-keterampilan tersebut agar lulusannya mampu berkomunikasi dan berwacana dalam bahasa Inggris pada tingkat literasi tertentu. Tingkat literasi dalam pembelajaran bahasa Inggris khususnya siswa sekolah Menengah Atas (SMA) adalah tingkat di mana siswa diharapkan mampu mengakses pengetahuan dengan kemampuan berbahasa.

Dalam lingkunganpendidikan, siswa dituntut mampu berbicara dalam proses pembelajaran. Siswa harus mampu mengutarakan gagasannya. Mereka juga harus dapat menjawab pertanyaan atau mengajukan pertanyaan dengan baik selama pembelajaran berlangsung. Para siswa dituntut mampu mengemukakan pendapat, mempertahankan pendapat, menyanggah pendapat siswa lain, atau mempengaruhi siswa lain agar mengikuti alur pemikirannya. Siswa boleh jadi sudah menguasai tata cara berbicara, tetapi kemampuan yang dikuasai itu terutama hanya berupa kemampuan berbicara dalam keadaan bertatap muka atau dalam kelompok kecil.

Dalam kenyataannya, banyak siswa yang berbicara secara resmi di depan umum kebanyakan hanya berupa pengajuan pertanyaan saja. Dalam aplikasi didalam kelas 
hampir tidak ada siswa yang mampu berbicara didepan kelas atau sekedar mengajukan pertanyaan. Kalaupun ada hanya satu atau dua orang saja yang mampu dan berani berbicara didepan kelas. Kelas terkesan mati karena tidak terjadi interaksi seperti yang seharusnya terjadi dalam proses pembelajaran. Padahal keberhasilan suatu pembelajaran dipengaruhi juga oleh keaktifan para siswa dalam mengikuti pembelajaran tersebut.

Banyak faktor yang mengakibatkan siswa susah dalam berkomunikasi diantaranya adalah kurangnya peran guru dalam memfasilitasi siswa dengan model dan media pembelajaran yang tepat. Selain faktor tersebut, ada faktor lain yang mempengaruhi kemampuan berbicara siswa diantaranya adalah rendahnya penguasaan kosakata, sulitnya siswa dalam menyusun kalimat yang baik, dan ketidak mampuan siswa mengembangkan gagasan, kebiasaan menggunakan bahasa ibu dalam berkomunikasi, baik di lingkungan sekolah, keluarga, dan masyarakat, dan juga seringnya para guru menggunakan teknikceramah untuk menjelaskan bahan ajar.

Berdasarkan hasil pengamatan awal yang peneliti lakukan disekolah tersebut, masih banyak siswa kelas XI jurusan Ilmu Alam (IA) yang sangat susah untuk berkomunikasi dalam hal ini untuk mengeluarkan apa yang mereka ingin utarakan. Siswa terlihat sangat ragu-ragu untuk mengeluarkan ide ataupun untuk mengeluarkan pendapat. Di samping itu, metode pengajaran yang diterapkan dikelas khususnya dalam mata pelajaran bahasa Inggris membuat siswa kurang tertarik dalam mata pelajaran tersebut. Guru cenderung menggunakan metode ceramah dalam proses pembelajaran di kelas.

Bertolak dari fenomena tersebut seorang guru haruslah mampu mengerti apa yang terjadi terhadap perserta didiknya. Seorang guru juga haruslah berperan sebagai fasilitator. Fasilitator dapat diartikan bahwa guru selainbertugas sebagai pengajar juga berperan sebagai pembimbing siswa dalam proses belajar mengajar. Tugas guru juga mendorong siswa untuk berpikir serius dan kreatif dalam menghadapi segala permasalahan belajar. Dengan kata lain, seorang guru harus dapat mengoprimalkan perannya sebagai fasilitator, sehingga guru perlu memahami hal-hal yang berhubungan dengan berbagai media dan sumber belajar. Oleh karena itu, sangat jelas bahwa untuk mewujudkan dirinya sebagai fasilitator, guru mutlak perlu menyediakan sumber dan media belajar yang cocok dan beragam dalam setiap kegiatan pembelajaran, dan tidak menjadikan dirinya sebagai satu-satunya sumber belajar bagi para siswanya. Oleh karena itu, seorang guru wajib mencari sumber belajar lain yang dapat merangsang dalam proses belajar mengajar yaitu salah satunya dengan bantuan media pengajaran seperti media gambar berseri.

Dina Indriana (2011:65) menjelaskan bahwa media gambar mampu memberikan detail dalam bentuk gambar apa adanya, sehingga anak didik mampu untuk mengingatnya dengan lebih baik dibanding dengan media verbal dan juga media gambar dapat memecahkan masalah yang ada dalam media oral atau verbal, yakni dalam keterbatasan daya ingat dalam bercerita atau menjelaskan sesuatu.

Dalam proses belajar mengajar kehadiran media mempunyai arti yang sangat penting, karena dapat mewakili apa yang kurang mampu guru ucapkan melalui kata-kata atau kalimat tertentu. Bahkan keabstrakan bahan dapat dikongkritkan dengan kehadiran media Artikel ini bertujuan untuk mengkaji secara mendalam mengenai penerapan media gambar berseri dalam meningkatkan kemampuan berbicara bahasa Inggris siswa. Kemampuan berbicara yang diukur dalam penelitian ini berdasarkan 5 aspek menurut Jack C. Richard dan Willi Renandya 
(2002:222-224) yaitu pelafalan, tata bahasa, kosa kata, kelancaran dan pemahaman.

\section{METODE}

Penelitian ini merupakan penelitian tindakan \{action research). Emzir (2013:223) mendeskripsikan penelitian tindakan merupakan suatu penelitian informal, kualitatif, formatif, subjektif, interpretif, reflektif, dan suatu model penelitian pengalaman, di mana individu dilibatkan dalam studi sebagai peserta yang mengetahui dan menyokong.

Senada dengan Emzir, Hopkins (2002:42) juga menjelaskan bahwa penelitian tindakan mengkombinasikan prosedur penelitian dengan tindakan substantif, suatu tindakan yang dilakukan dalam disiplin ingkuiri, atau suatu usaha seseorang untuk memahami apa yang sedang terjadi, sambil terlibat dalam sebuah proses perbaikan dan perubahan. Dengan kata lain penelitian tindakan berarti mengujicobakan gagasan dalam praktek sebagai sarana perbaikan dan peningkatan pemahaman mengenai kurikulum, metode dan strategi pembelajaran, proses pembelajaran yang hasilnya berupa perbaikan terhadap apa yang terjadi dalam pelaksanaan proses pembelajaran tersebut, khususnya yang terjadi dikelas.

Disamping itu L.R. Gay (2011:508) juga memberikan pengertian bahwa penelitian tindakan adalah penyelidikan sistemaris yang dilakukan oleh guru, kepalasa sekolah, konselor sekolah, atau stakholder lainnya dalam lingkungan belajar mengajar dan juga melibatkan pengumpulan informasi tentang tata cara guru dan siswa dalam proses belajar mengajar. Sehingga penelitian tindakan merupakan penelitian dimana semua partisipan terlibat dalam penelitian tersebut

Dalam penelitian ini, peneliti mengambil model penelitian tindakan Kemmis. Kemmis dalam Emzir (2013:239) model sederhana hakikat siklus proses penelitian tindakan yang setiap siklus mempunyai empat tahapan yaitu (1) perencanaan; (2) tindakan; (3) observasi; (4) refleksi. Keempat konsep tersebut dalam pengkajiannya dilakukan secara berbaur, bertahap, dan sistematis. Model Kemmis bila dicermati hakekatnya berupa perangkatperangkat atau untaian - untaian dengan satu perangkat terdiri dari empat komponen yaitu perencanaan, tindakan, pengamatan dan refleksi, karena dalam model ini menyatukan dua komponen antara implementasi acting dan observing karena dua kesatuan tersebut tidak dapat dipisahkan. Dalam hal ini kedua kegiatan tersebut harus harus dilakukan dalam kesatuan waktu yang sama, ketika berlangsungnya suatu tindakan maka begitu pula observasi harus dilaksanakan

Penelitian tindakan ini merupakan rangkaian penelitian yang dilakukan secara siklik yang masing-masing siklus terdiri dari 4 kegiatan utama yaitu pembuatan rencana (plan), pelaksanaan tindakan \{action), pemantauan (observation), dan refleksi (reflection) dalam rangka memecahkan masalah hingga masalah itu terpecahkan.

Penelitian ini dilakukan di SMA Negeri 5 Kendari, Sulawesi Tenggara dari bulan Januari hingga Maret. Data diperoleh dari siswa kelas XI IA 2 pada semester kedua dengan jumlah siswa 42 orang. Data hasil penelitian kemudian dianalisis secara kuantitatif dengan cara hasil setiap tes yang dilakukan setiap akhir pertemuan ditiap siklusnya dan juga secara kualitatif yaitu dengan cara mendeskripsikan hasil observasi. Tes percakapan dilakukan sebanyak 3 kali di setiap akhir siklus. Tes ini berupa gambar berseri yang diberikan kepada siswa yang dipersiapkan oleh peneliti dan dipresentasekan di depan kelas.

Adapun instrument penelitian yang digunakan diadaptasi berdasarkan tingkat kemampuan berbicara menurut Jack C. Richard dan Willy A. Renandya (2002:222- 
224). Aspek-aspek yang diukur dalam penelitian ini adalah pelafalan, tata bahasa, kosa kata, kelancaran, dan pemahaman. Sebelumnya, instrumen telah diperiksa validitasnya melalui penilaian para ahli dan kemudian validasi data diperiksa melalui teknik triangulasi.

Patokan penilaian siswa menurut Richard dan willy dikelompokkan sebagai berikut

\section{Tabel 1}

\section{CONVERSATIONAL ENGLISH PROFICIENCY RATING}

Rating Sheet :

Name

Rate

Date

\begin{tabular}{|c|c|c|c|c|c|c|c|}
\hline \multicolumn{8}{|c|}{ Conversational English Proficiency Weighting Table } \\
\hline Proficiency Description & 1 & 2 & 3 & 4 & 5 & 6 & Total \\
\hline Accent & & & & & & & \\
\hline \multicolumn{8}{|c|}{ Conversational English Proficiency Weighting Table } \\
\hline \multicolumn{8}{|l|}{ Grammar } \\
\hline \multicolumn{8}{|l|}{ Vocabulary } \\
\hline \multicolumn{8}{|l|}{ Fluency } \\
\hline \multicolumn{8}{|l|}{ Comprehension } \\
\hline \multicolumn{8}{|l|}{ Total } \\
\hline \multicolumn{2}{|l|}{ Total } & \multicolumn{6}{|c|}{ Level } \\
\hline \multicolumn{2}{|l|}{$16-25$} & \multicolumn{6}{|c|}{$0+$} \\
\hline \multicolumn{2}{|l|}{$26-32$} & \multicolumn{6}{|c|}{1} \\
\hline \multicolumn{2}{|l|}{$33-42$} & \multicolumn{6}{|c|}{$1+$} \\
\hline \multicolumn{2}{|l|}{$43-52$} & \multicolumn{6}{|c|}{2} \\
\hline \multicolumn{2}{|l|}{$53-62$} & \multicolumn{6}{|c|}{$2+$} \\
\hline \multicolumn{2}{|l|}{$63-72$} & \multicolumn{6}{|c|}{3} \\
\hline \multicolumn{2}{|l|}{$73-82$} & \multicolumn{6}{|c|}{$3+$} \\
\hline \multicolumn{2}{|l|}{$83-92$} & \multicolumn{6}{|c|}{4} \\
\hline \multicolumn{2}{|l|}{$93-99$} & \multicolumn{6}{|c|}{$4+$} \\
\hline
\end{tabular}

Keberhasilan dari tindakan ini terlihat dari adanya peningkatan atau kemajuan pada proses pembelajaran yaitu hasil peningkatan kemampuan berbicara bahasa Inggris siswa. Kemampuan berbicara siswa menunjukkan peningkatan dalam hal pelafalan, kosakata, tata bahasa, kelancaran, dan pemahaman. Selain itu adalah sikap perubahan siswa yang menunjukkan antusias yang baik dan berpartisipasi aktif selama kegiatan berlangsung, percaya diri dalam bertanya dan mengeluarkan pendapat.

\section{HASIL}

Tindakan yang dilakukan penelid pada siklus pertama menghasilkan peningkatan terhadap kemampuan berbicara berdasarkan rerata skor yang meningkat yaitu sebanyak 53,21 dari skor tes awal yaitu 41,60. Pada akhir siklus pertama terlihat skor tertinggi 
yaitu 64,5 dan skor terendah adalah 49,5. Pada akhir siklus pertama ini terlihat ada beberapa aspek yang terlihat masih rendah. Oleh karena itu dilakukan siklus kedua untuk melihat hasil peningkatan dari dari siklus II.

Tindakan pada siklus kedua ini penelid memberikan kembali gambar berseri kepada siswa. Pemberian gambar berseri ini dimaksudkan untuk memperkuat peningkatan kemampuan berbicara bahasa Inggris siswa pada siklus I. Pada siklus kedua ini sudah terlihat peningkatan dari beberapa aspek kemampuan tetapi belum sesuai dengan hasil yang diharapkan. Pada siklus kedua ini terlihat peningkatan rerata dari siklus I yaitu menjadi 66,56. Oleh sebab itu, untuk mencapai tujuan penelitian peneliti melaksanakan siklus ketiga.
Peneliti kemudian melakukan revisi rencana dan pelaksanaan tindakan pada siklus ketiga. Tindakan yang dilakukan adalah masih sama seperti siklus-siklus sebelumnya yaitu dengan memberikan gambar berseri kepada siswa, yaitu dengan melihat hasil yang kurang pada siklus kedua seperti pelafalan, tatabahasa, dan kosa kata siswa. Pada siklus ketiga ini terjadi peningkatan rerata dari siklus kedua yaitu 74,64. Adapun peningkatan kemampuan siswa dilihat dari tahap pre tes samapi dengan akhir siklus ketiga dapat dilihat pada gambar berikut:

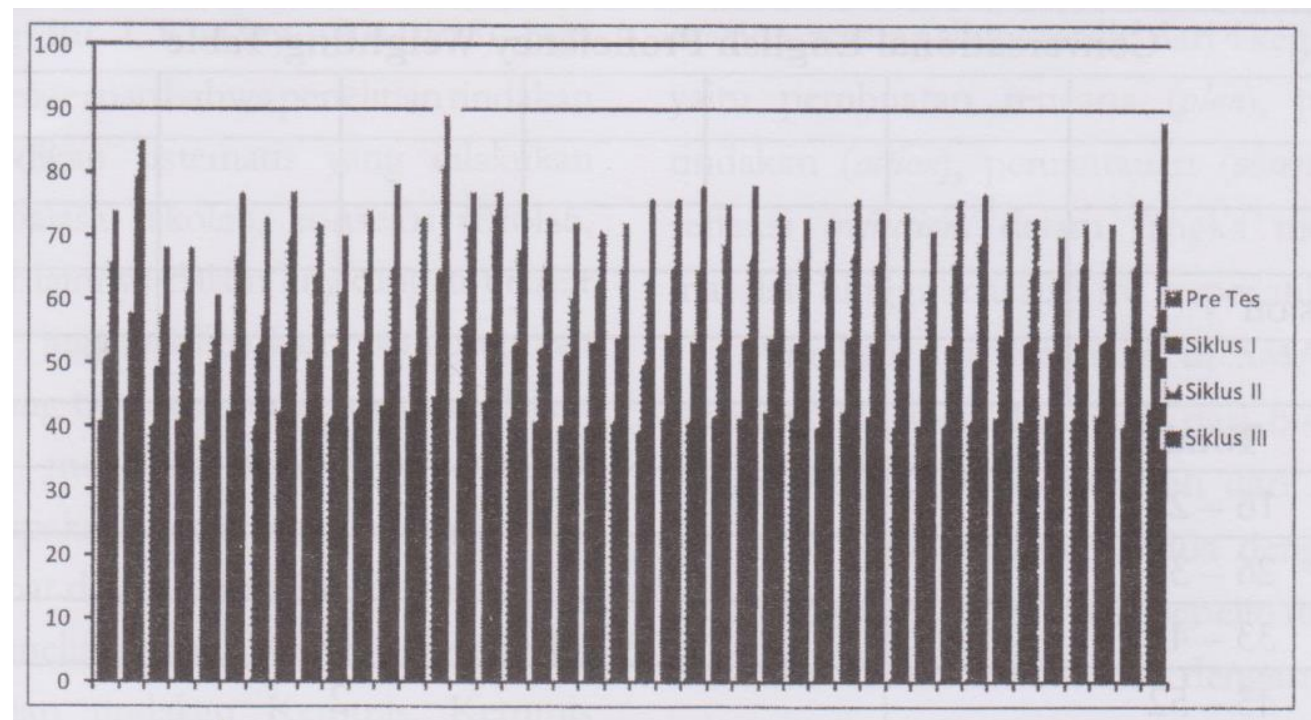

Gambar 1. Peningkatan Kemampuan Berbicara Bahasa Inggris Pretes sampai Siklus III

Gambar diatas menunjukkan bahwa ada peningkatan kemampuan berbicara dari tahap pre tes sampai dengan siklus ketiga. Jadi, dapat disimpulkan bahwa media gambar berseri efetif dalam meningkatkan kemampuan berbicara bahasa Inggris siswa.

\section{PEMBAHASAN}

Hasil penelitian selama tiga siklus ini membuktikan bahwa penggunaan media gambar berseri merupakan alternatif yang baik untuk meningkatkan kemampuan berbicara bahasa Inggris siswa kelas XI IA 2 SMA Negeri 5 Kendari. Pada awal penerapan media gambar berseri ini ditemukan kendala dalam mengajak siswa. Siswa masih merasa baru dalam penerapan media gambar berseri ini. Namun, secara bertahap penerapan media gambar berseri ini menunjukkan peningkatan yang signifikan. Penerapan media gambar berseri ini juga sangat membantu dalam menumbuhkan kepercayaan diri kepada siswa 
dalam mengungkapkan atau mengeluarkan pendapat dalam bahasa Inggris.

Selain itu, pemanfaatan media gambar berseri bisa membuat siswa kreatif dalam mengungkapkan apa yang mereka akan ungkapkan. Pada mulanya, peneliti juga melihat masih banyak siswa yang malu-malu dan raguragu dalam berbicara di depan kelas, terlebih karena belum terbiasa berbicara di depan kelas dan disaksikan oleh teman sekelasnya. Hal ini diakibatkan kurangnya rasa percaya diri dan keberanian siswa untuk berbiara bahasa Inggris. Akan tetapi setelah diberi motivasi dari peneliti dan kolaborator kepercaya dirian siswa meningkat sehingga pada umumnya di siklus ketiga siswa tidak mengalami masalah dalam berbicara di depan kelas.

Kemudian, penggunaan media gambar berseri ini menunjukkan adanya peningkatan kemampuan berbicara bahasa Inggris siwa secara bertahap. Kemampuan berbicara siswa dalam tes awal menunjukkan hasil yang kurang maksimal dibandingkan kemampuan berbicara bahasa Inggris mereka pada akhir siklus I. Dari hasil pengamatan diketahui bahwa rasa malu-malu dan ragu-ragu serta kurangnya rasa percaya diri siswa adalah merupakan salah satu faktor yang menghambat peningkatan kemampuan siswa dalam berbicara bahasa Inggris.

Disamping itu, dengan penggunaan media gambar berseri membuat kekompakkan siswa semakin erat, karena peneliti di setiap pelaksanaan dndakan membagi siswa dalam kelompok-kelompok diskusi. Selain itu, peneliti juga melihat siswa juga lebih terampil dan berani dalam mengajukan pertanyaan, menyampaikan jawaban serta mengajukan komentar dalam bahasa Inggris.

\section{KESIMPULAN}

Bahasa Inggris sebagai sarana berkomunikasi merupakn suatu bentuk kinerja dan performasi yang bagi orang Indonesia perlu dilatih secara terus menerus baik dalam berkomunkasi secara lisan maupun tertulis. Sebagai konsekuensinya, pembelajaran bahasa Inggris disekolah harus lebih menekankan pada fungsi bahasa sebagai alat komunikasi ketimbang pembelajaran tentang sistem bahasa. Pada aspek berbicara yang merupakan bagian dari empat keterampilan bahasa yang perlu dikuasai siswa untuk dapat dikatakan bahwa siswa tersebut terampil. Maka semestinya pembelajaran bahasa dapat ditekankan pada praktek dab ladhan. Kemudian selain itu juga pembelajaran haruslah terprogram dan terencana demi kebermaknaan kegiatan dan keberhasilan mencapai tujuan kegiatan tersebut.

Berbicara merupakan salah satu kemampuan yang harus diberikan dan dilatihkan pada siswa SMA kelas XI pada pada usia ini siswa seharusnya telah memiliki kemampuan untuk berbicara. Namun dalam kenyataannya, siswa SMA kelas XI masih mengalami kesulitan dalam hal berbicara. Disamping banyak faktor ketidakpastian dan ketidak berhasilan siswa dalam berbicara bahasa Inggris; waktu yang terbatas, minat siswa terhadap berbicara rendah ataupun kurangnya kreadvitas serta inovasi dari guru.

Maka dalam penelitian ini penulis menawarkan media gambar berseri sebagai alternatif teknik mengajar kemampuan berbicara bahasa Inggris. Pembelajaran berbicara bahasa Inggris dengan menggunakan media gambar berseri ternyata mampu meningkatkan kemampuan berbicara siswa kelas XI IA 2, SMA Negeri 5 Kendari. Kekuatan dari media gambar berseri adalah mampu merangsang minat dan kemampuan siswa dalam proses pembelajaran berbicara bahasa Inggris.

Pembelajaran berbicara bahasa Inggris dengan menggunakan media gambar berseri 
juga memberi kreatifitas yang sangat tinggi kepada siswa. Siswa menjadi senang belajar dan mereka merasa bahwa dengan belajar berbicara dengan media gambar berseri siswa merasa senang dan tidak tertekan. Diharapkan dengan adanya penelitian tindakan kelas ini, siswa termotivasi untuk dapat meningkatkan kemampuan dalam hal berbicara bahasa Inggris.

Proses kegiatan belajar-mengajar yang diberikan adalah menggunakan aspek-aspek peningkatan kemampuan berbicara bahasa Inggris yaitu tata bahasa, pelafalan, dan kosakata. Adapun tahapan dalam kegiatannya secaara umum yaitu; (1) tahap persiapan; peneliti mempersiapkan semua materi gambar yang akan digunakan, menentukan kompetensi dan lain-lain (2) tahap presentasi atau penyajian, (3) tahap latihan dan (4) tahap evaluasi.

Penelitian tindakan ini menggunakan tiga siklus dengan langkah-langkah sebaga berikut : (1) observasi awal (2) perencanaan (3) tindakan (4) observasi dan refleksi.

\section{IMPLIKASI}

Berdasarkan kesimpulan yang diperoleh dari penelitian ini, dapat dikemukakan implikasi sebagai berikut:

1. Guru perlu memberikan teknik pembelajaran yang bervariasi sehingga siswa merasa tertantang untuk berbicara bahasa Inggris.

2. Guru yang mengampu mata pelajaran bahasa Inggris di SMA Negeri 5 Kendari, sebelum menerapkan teknik bercerita, terlebih dahulu harus mengetahui tingkat kemampuan siswa khususnya yang berkaitan dengan kemampuan berbicara.

3. Dengan menggunakan media gambar berseri dapat memberikan peningkatan bukan hanya kemampuan berbicara saja namun dapat meningkatkan keterampilan membaca, menulis, mendengar atau menyimak.

\section{DAFTAR PUSTAKA}

Emzir. Metodologi Penelitian Pendidikan Kuantitatif dan Kualitatif. Jakarta: PT. Raja Grafmdo Persada, 2013

Hopkins, David. A Teacher's Guide to Classroom Research, Third Edition. Philadelphia: Buckingham, 2002

Indriana, Dina. Ragam Alat Bantu Media Pengajaran. Jogjakarta: Diva Press, 2011

Gay, L.R. dkk. Educational Research, Competencies for Analysis and Applications Tenth Edition. USA:Pearson Education, Inc 2011

Richard, Jack C. And Willy Renandya. Methodology in Language Teaching. UK: Cambridge University Press, 2002

Thornbury, Scott. How to Teach Speaking. UK: Pearson Education, 2008. 